\title{
豚ふん尿の熱処理によるメタン発酵能向上に関 する研究
}

\author{
土手 裕 $^{1 *}$ ・関戸知雄 ${ }^{1} \cdot$ 後藤吉史 ${ }^{2} \cdot$ 鈴木祥広 $^{1}$ \\ 1 宮崎大学工学部土木環境工学科（ $\overline{7} 889-2192$ 宮崎市学園木花台西 1-1) \\ 2 三浦工業株式会社（†799-2696 愛媛県松山市堀江町 7 番地） \\ *E-mail:dote@civil.miyazaki-u.ac.jp
}

\begin{abstract}
豚ふん尿の熱処理によるメタン発酵性能への影響を評価するために、バッチおよび連続式のメタン発

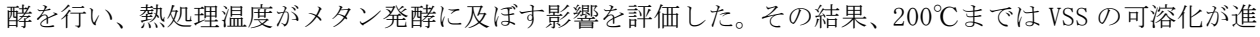
むが、高分子の溶存性 TOC 成分の VFA 化はあまり進まないことが分かった。熱処理温度が高くなるとメ タン発酵開始時期およびメタン発酵速度が遅くなり、 $250^{\circ} \mathrm{C} て ゙$ 処理した場合はメタン発酵しなかった。 $150^{\circ} \mathrm{C}$ で熱処理した場合、投入VS あたりメタン発生量は 1.2 倍になり、熱処理による効果が見られた。 エネルギー回収の観点からは、熱処理を行う場合は不利であり、SS 濃度を 2.3 倍以上に濃縮した液を熱 処理することで、熱処理なしに比べて正味のエネルギー回収が多くなると見積もられた。
\end{abstract}

Key Words: pig manure, thermal treatment, methane fermentation, energy balance

\section{1.はじめに}

近年、家畜排せつ物は、その不適切な処理のため深 刻な水質污染や悪臭問題の原因となっている。その ため、家畜排せつ物の適正な処理を定めた法律が平 成16年11月に完全施行され、家畜排せつ物処理設備 の整備が進められている。家畜排せつ物の発生量は 年間 8,769 万トンであり ${ }^{1)}$ 、そのうち豚の排せつ物発 生量は26\%を占めており、豚ふん尿の適切な処理は重 要である。家畜排せつ物の利用の促進を図るための 基本方針では ${ }^{2)}$ 、家畜排せつ物の堆肥化利用を推進 するとする一方で、堆肥が需要量を超えて発生して いる地域については、家畜排せつ物のエネルギー利 用等の堆肥以外の利用方法を図ることが重要である とされている。

家畜排せつ物のエネルギー利用法の一つとしてメ タン発酵があるが、固形物を含む原料の場合、固形 物の可溶化がメタン発酵効率を向上させるために有 効であることが指摘されている ${ }^{3)}$ 。可溶化方法の一つ である熱処理は、温度を高くすることで加水分解に よる可溶化、低分子化を促進寸る。また、熱分解、 再結合、脱水縮合などのラジカル反応により二酸化 炭素や揮発性有機低分子物質が生成されるガス化が 同時に進行し、温度が高いほどラジカル反応が激し くなる。 ${ }^{4,5,6,7)}$

メタン発酵の前処理としての熱処理については、下 水污泥を対象とした多くの研究があり $8,9,10,11$ 、コス
卜的にも現実的であるという報告がある ${ }^{12)}$ 。一方、 熱処理により副次的にメタン発酵阻害物質の生成が 報告されている ${ }^{12)}$ 。

また、メタン発酵の前処理としての熱処理について は、下水污泥以外に、㴻芥 ${ }^{3)}$ 、牛尔ん ${ }^{13)}$ については 連続式のメタン発酵で熱処理効果が検討されている。 豚ふん尿についてバッチ式による検討は行われてい るが（熱処理温度は $190^{\circ} \mathrm{C}$ まで） ${ }^{14)}$ 、連続式メタン発 酵による検討は行われていない。処理対象物の性状 を見ると下水污泥は微生物主体、厨芥は消化を受け る前のもの、牛ふんは草と穀類が主体の飼料を消化 したものでトウモロコシなどの穀類主体の飼料を用 いる豚と異なっている。よって、豚ふん尿の熱処理 効果はこれらとは異なる可能性がある。

本研究では、豚ふん尿を対象にメタン発酵の前処理 としての熱処理効果を評価すること目的として、熱 処理条件の処理液性状への影響と、バッチ式および 連続式メタン発酵実験によりメタン発酵への影響を 明らかにした。さらにエネルギー収支を検討した。

\section{2. 実験方法}

\section{（1）熱処理条件および豚ふん尿}

熱処理の種類と熱処理条件を表-1に示す。熱処理 A は処理時間の影響を調べるために予備的に行った。 熱処理 B は処理温度の影響を調べるため、熱処理 C、 D はそれぞれバッチ式、連続式のメタン発酵実験用の 
表-1 熱処理条件

\begin{tabular}{|c|c|c|c|c|}
\hline & 熱処理 $\mathrm{A}$ & 熱処理 B & 熱処理 C & 熱処理D \\
\hline $\begin{array}{l}\text { 熱処理目 } \\
\text { 的 }\end{array}$ & $\begin{array}{l}\text { 処理時間 } \\
\text { の検討 }\end{array}$ & $\begin{array}{l}\text { 処理温度 } \\
\text { の検討 }\end{array}$ & $\begin{array}{l}\text { バッチメ } \\
\text { タン発酵 } \\
\text { 用基質 }\end{array}$ & $\begin{array}{l}\text { 連続メタ } \\
\text { ン発酵用 } \\
\text { 基質 }\end{array}$ \\
\hline 採取場所 & $\mathrm{A}$ 養豚場 & $\begin{array}{l}\text { メタン発 } \\
\text { 酵プラン } \\
\text { 卜 }\end{array}$ & $\begin{array}{l}\text { メタン発 } \\
\text { 酵プラン } \\
\text { 卜 }\end{array}$ & $\mathrm{A}$ 垗豚場 \\
\hline $\begin{array}{l}\text { 熱処理温 } \\
\text { 度 }\left({ }^{\circ} \mathrm{C}\right)\end{array}$ & $150 \sim 300$ & $150 \sim 250$ & $150 \sim 250$ & 150 \\
\hline $\begin{array}{l}\begin{array}{l}\text { 処理時間 } \\
\text { (分) }\end{array} \\
\end{array}$ & $10 \sim 120$ & 10 & 10 & 10 \\
\hline
\end{tabular}

基質を作成するために行った。

実験に用いた豚ふん尿は、熱処理 A,D こついては 宮崎県内の A 養豚農家から採取した。熱処理 B, C で 用いた豚ふん尿は、宮崎大学内に設置された豚ふんん 尿を原水とする小型メタン発酵プラントの原水槽か ら採取した。いずれの豚ふん尿も目開き $2 \mathrm{~mm}$ の篩で 異物を除去した後、冷凍保存し、使用する前日に解 凍して実験に用いた。

\section{（2）熱処理方法}

熱処理にはオートクレーブ (鈴木商工 (株)、有効容 積 $300 \mathrm{~mL}$ ) を用いた。このオートクレーブに所定量の 豚ふん尿を加えて密閉後、容器内の空気を窒素ガス で置換し、窒素ガスで初期圧を $1 \mathrm{MPa}$ に調整した。 100rpm で擋找を行いながらニクロム線による外部ヒ ーターでオートクレーブ全体の加熱を行なった。所 定の設定温度に達した後、所定時間その温度を保持 した後、外部ヒーターを取り除き、扇風機を用いて 冷却した。設定温度までの加熱時間および冷却時間 には、それぞれ約 1 時間、30 分を要した。設定温度 に達してから泠却するまでを熱処理時間と呼ぶこと とする。

熱処理 A, B では、充填量は $100 \mathrm{~mL}$ とし、熱処理後の 内容物の全量を回収した。シャフトおよびオートク レーブを蒸留水で洗浄し、洗浄液も回収した。これ らの回収物を良く混合して分析試料とした。この液 は洗浄用の蒸留水で希釈されていることから、希釈 効果を補正して熱処理液の結果として用いた。

また、熱処理 B では C, N の物質収支を検討するため に、冷却後のオートクレーブのガスの出口側に硫酸 (0.1M, 200mL) の入ったガス洗浄管と湿式ガスメータ (SHINAGAWA，WS-1A)、テドラーバックを直列に連結 してからガスを排出した。ガス洗浄管の硫酸溶液を ガス中アンモニアの分析用試料とした。ガス量は湿 式ガスメータで測定した。テドラーバックに捕集し たガスをガス組成分析用試料とした。

メタン発酵用基質を作るための熱処理 C, D では、熱 処理液を熱処理 $A, B$ と同様に回収したが、蒸留水に よるオートクレーブ内の洗浄は行わなかつた。洗浄 を行わなかった理由は、蒸留水添加による熱処理液

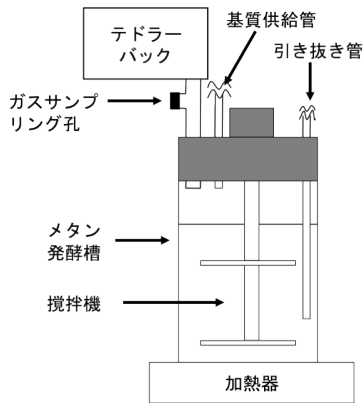

図-1 連続メタン発酵装置

の希瀵を避けて、未処理の豚ふん尿の結果と直接比 較を行うためである。メタン発酵には多くの基質を 必用としたので複数回の熱処理を行い、全回収液を 混合したものを基質として用いた。

\section{（3）バッチ式メタン発酵実験}

$300 \mathrm{ml}$ のガラス製三角フラスコに基質 $200 \mathrm{~mL}$ と植種 液として下水消化污泥を $20 \mathrm{~mL}$ 加え、フラスコ内の空 気を窒素でパージしてシリコン栓で密封した。シリ コン栓の外側には発生ガスを集めるためのテドラー バックを付けた。テドラーバックとシリコン栓の間 にガラス製のT字管をおき、ガス濃度分析用のガス を採取した。三角フラスコを $36^{\circ} \mathrm{C}$ 設定したインキ ユベータ内に置き、1 日に 2 回フラスコを攪拌し、1 週間に 2 回の頻度でガス組成 $\left(\mathrm{CO}_{2}, \mathrm{O}_{2}, \mathrm{~N}_{2}, \mathrm{CH}_{4}\right)$ 及びガ ス発生量を測定した。累積メタンガス量が一定とな ったところで、メタン発酵実験を終了とした。ガス 発生量はテドラーバックを外して、テドラーバック 内のガス量を水上置換により測定した。測定後、十 分窒素パージしたテドラーバックを三角フラスコに 再度取り付けた。

基質としては、未処理の豚ふん尿および表 1 に示し た条件で熱処理した豚ふん尿を用いた。各基質につ き 3 セット反応容器を用意した。

\section{（4）連続式メタン発酵実験}

連続式メタン発酵実験には、眓-1に示すメタン発酵 装置(エイブル社、BMJ、容量 $1 \mathrm{~L}$ )を用いて行った。 発酵槽温度は発酵槽底部にある加熱器により制御し $36^{\circ} \mathrm{C}$ に設定した。擋挥速度は約 $140 \mathrm{rpm}$ とし、槽内を 混合することで固形物の沈殿を抑制した。基質は 1 日 1 回基質供給管からシリンジで供給し、発酵処理 液は 1 日 1 回引き抜き管からシリンジで所定量を引 き抜いた。発生したガスは、テドラーバックにより 捕集し、1 日に 1 回所定時刻に発酵槽から取り外し、 水上置換により発生量の測定を行った。図には省略

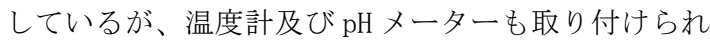
ている。 
表-2 熱処理に用いた豚ふん尿の性状

\begin{tabular}{|l|r|r|r|r|r|}
\hline & $\begin{array}{l}\text { 熱処理 } \\
\text { A }\end{array}$ & $\begin{array}{l}\text { 熱処理 } \\
\text { B }\end{array}$ & $\begin{array}{l}\text { 熱処理 } \\
\text { C }\end{array}$ & $\begin{array}{l}\text { 熱処理 } \\
\text { D }\end{array}$ & 文献 ${ }^{14)}$ \\
\hline $\mathrm{pH}$ & 6.87 & 6.92 & 6.87 & 6.46 & - \\
\hline $\begin{array}{l}\mathrm{TS} \\
(\mathrm{mg} / \mathrm{L})\end{array}$ & - & 29,700 & 53,400 & 72,200 & - \\
\hline $\begin{array}{l}\mathrm{VS} \\
(\mathrm{mg} / \mathrm{L})\end{array}$ & - & 21,700 & 38,200 & 55,300 & - \\
\hline $\begin{array}{l}\mathrm{SS} \\
(\mathrm{mg} / \mathrm{L})\end{array}$ & 15,100 & 24,500 & 48,800 & 53,000 & 80,000 \\
\hline $\begin{array}{l}\mathrm{VSS} \\
(\mathrm{mg} / \mathrm{L})\end{array}$ & 12,700 & 19,500 & 36,900 & 40,900 & - \\
\hline $\begin{array}{l}\mathrm{TC} \\
(\mathrm{mg} / \mathrm{L})\end{array}$ & 8,540 & 6,890 & 8,210 & - & - \\
\hline $\begin{array}{l}\mathrm{D}-\mathrm{TOC} \\
(\mathrm{mg} / \mathrm{L})\end{array}$ & 8,540 & 6,600 & 8,210 & 6,750 & - \\
\hline $\begin{array}{l}\mathrm{T}-\mathrm{N} \\
(\mathrm{mg} / \mathrm{L})\end{array}$ & 2,290 & 2,240 & 3,100 & - & 6,800 \\
\hline $\begin{array}{l}\mathrm{NH} \mathrm{H}_{4}-\mathrm{N} \\
(\mathrm{mg} / \mathrm{L})\end{array}$ & 2,130 & 2,030 & 2,970 & 1,430 & - \\
\hline $\begin{array}{l}\text { 固形物 } \\
\text { 中 TC } \\
(\%-S S)\end{array}$ & 50 & 43 & 42 & - & - \\
\hline $\begin{array}{l}\text { 固形物 } \\
\text { 中 IC } \\
(\%-S S)\end{array}$ & 0.3 & 0.3 & 0.4 & - & - \\
\hline $\begin{array}{l}\text { 固形物 } \\
\text { 中 T } \\
\mathrm{N}(\%-\mathrm{SS})\end{array}$ & 5.5 & 3.9 & 2.5 & - & - \\
\hline
\end{tabular}

本実験は、メタン発酵装置を 2 台用意し、未処理 豚ふん尿を基質とした対照系と、処理温度 $150^{\circ} \mathrm{C}$ 、処 理時間 10 分の条件で熱処理した豚ふん尿を基質とし た熱処理系の 2 系列を同時に運転した。発酵槽には 上述した宮崎大学の小型メタン発酵プラントの処理 液 $700 \mathrm{~mL}$ を植種液として最初に充填した。設定 HRT は20日, 15 日, 10 日, 5 日の順で変化させた。引き抜 き液の TOC およびメタンガス発生速度が一定となっ たと確認したところで次の HRT に変更した。処理液 の分析は通常は TOC のみを行い、定常に達した場合 には、HRT を変更する直前 3 日分の処理液を混合して TS, VS, SS, VSS の分析を行った。

\section{(5) 分析項目、分析方法}

豚ふん尿、熱処理液、メタン発酵処理液については、 TS，VS，SS，VSS は下水道試験法に従って分析した。 試料水を孔径 $1.0 \mu \mathrm{m}$ のメンブランフィルターを用い て、ろ液を得た。ろ液中の TC, IC, TOC は TOC 分析 装置 (SHIMADZU，TOC-5000) で分析した。なお、ろ液 中の $\mathrm{TOC}$ を D-TOC と表記する。VFA は GC-FID (SHIMADZU, GC-8APF) で分析した。ろ液中の全 窒素は TOC 分析装置 (SHIMADZU, TOC-VCPH, 窒素分析 モジュール TNM-1) を用いて、アンモニア性窒素はイ ンドフェノール青法で分析を行った。試料水中の固 形物については、試料水を遠心分離 (3000rpm, 15min) 後、上澄み液を捨て、蒸留水を加えて固形物を眯濁 させ、再度遠心分離を行い、沈殿した固形物を $105^{\circ} \mathrm{C}$ で 24 時間乾燥させて固形物を回収した。固形物中の 窒素含有量はアルカリ性ペルオキソ二硫酸カリウム

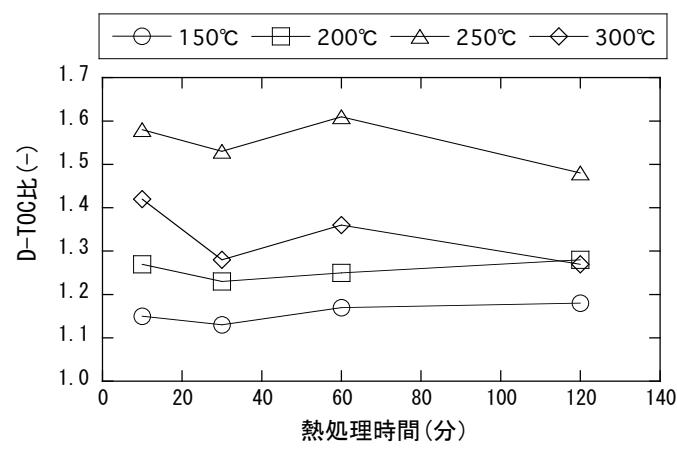

図-2Ｄ-TOC 比と熱処理時間の関係

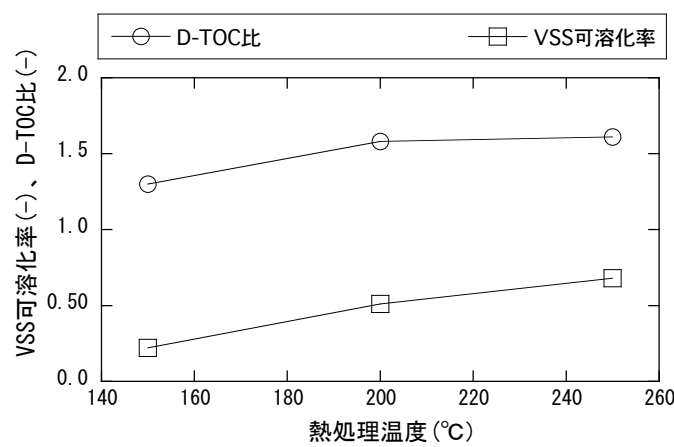

図-3 熱処理温度の影響

分解一紫外線吸光光度法で、TC 及び IC は TOC 分析装 置 (SHIMADZU, TOC-VCPH, 固形物燃焼ユニット SSM-5000A) を用いて分析した。ガス組成 $\left(\mathrm{CH}_{4}, \mathrm{CO}_{2}\right)$ は GC-TCD (SHIMADZU, GC-8A)にて分析した。

\section{3. 結果と考察}

\section{（1）熱処理条件の処理液性状への影響 \\ a) 用いた豚ふん尿の性状}

用いた豚ふん尿の性状を表-2に示す。実験で用いた ふん尿の SS, T-N が文献值と低くなっているが、これ は用いたふん尿には畜舎の洗浄水などが混入してい るためと考えられる。水溶性全窒素のうち $90 \%$ 以が アンモニア性窒素であった。SS のうち約 80\%がVSS であった。

\section{b) 熱処理時間の検討}

熱処理時間の影響を検討するために、原料の D-TOC に対する処理液の D-TOC の比（D-TOC 比）と熱処理時 間との関係を求めた（図-2)。いずれの熱処理温度で も熱処理時間 10 分で D-TOC 比が 1 を越え、有機施物

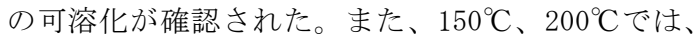
熱処理時間 10 分と 120 分の間の D-TOC 比の違いはわ ずかであった。 $250^{\circ} \mathrm{C}$ 以上では熱処理時間の増加と共 に D-TOC 比の減少が認められた。これは熱処理時間 が長くなるにつれて炭素が D-TOC からガス $\left(\mathrm{CO}_{2}\right)$ に変 わる反応 (ガス化) が進んだためと考えられた。 $300^{\circ} \mathrm{C}$

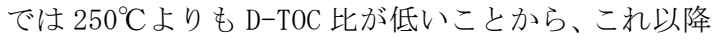




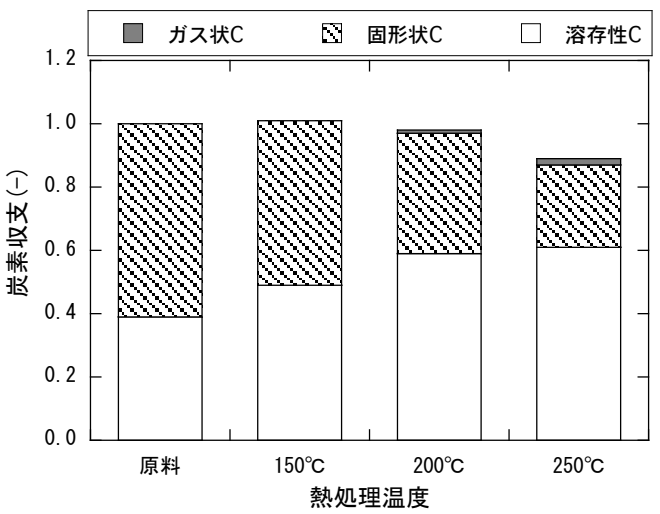

図-4 炭素収支

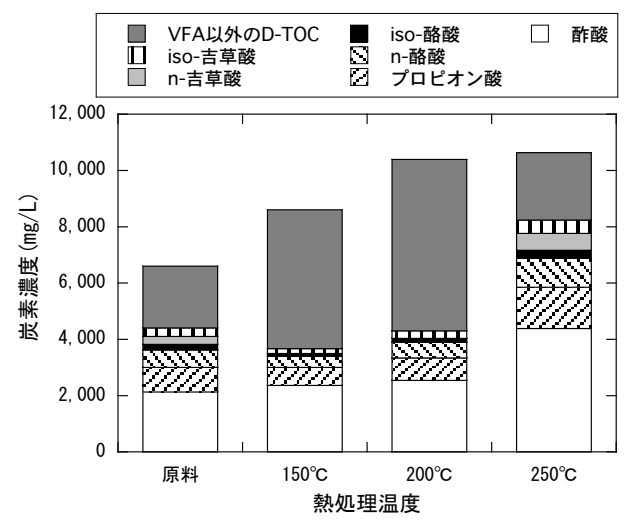

図-5 D-TOC の内訳

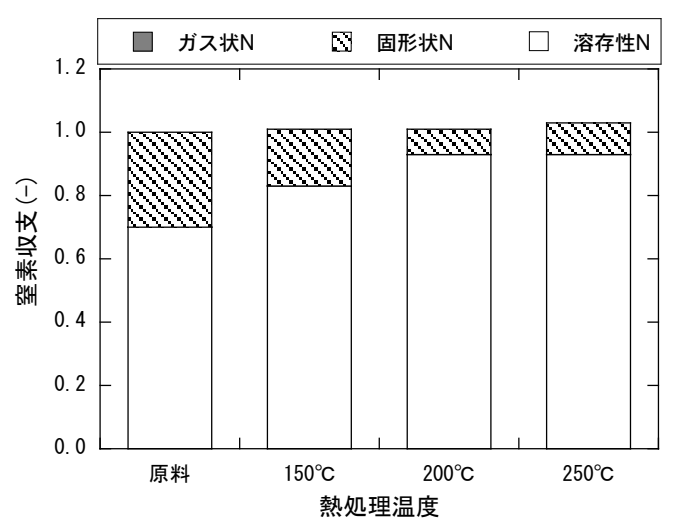

図-6 窒素収支

性がある。

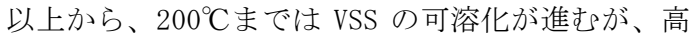
分子の D-TOC 成分の VFA 化はあまり進まないことが

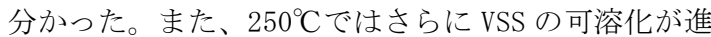
むと同時に、高分子の D-TOC 成分の低分子化および 若干のガス化が進むことが分かった。

\section{e) 熱処理温度のNバランス、アンモニア性窒素への \\ 影響}

原料中の窒素に対する反応後の窒素収支を図-6に 示す。処理温度の増加と共に、溶存性窒素の増加が 見られたが、炭素と同様に $200^{\circ} \mathrm{C}$ と $250^{\circ} \mathrm{C}$ 差は小さ かった。また、ガス状窒素の生成は認められなかっ た。データは示さないが、いずれの処理温度でも反 応液中のアンモニア性窒素の濃度は原料中の濃度と 同じであった。このことから、熱処理によりVSS 中 の窒素化合物は可溶化するが、 $250^{\circ} \mathrm{C}$ 以下ではアンモ ニアまでには分解されないことが分かった。Carrére ら ${ }^{14)}$ は、豚ふん尿を $150^{\circ} \mathrm{C}$ で処理した場合、未処理 に比べてアンモニア性窒素度が 1.2 倍に増加したと 報告している。熱処理のアンモニア性窒素濃度への 影響も䣷酸と同様に、用いる「豚ふん尿」によって 異なる結果が得られる原因として、慨となる飼料の 影響を受ける可能性がある。 


\section{（2）バッチによるメタン発酵実験}

表- 3 に基質として用いた熱処理液および植種に用 いた消化污泥の性状を示す。図-7にVS あたりの累積 メタン発生量（平均值）の経時変化を示寸。未処理 条件は 19 日目にメタン発生が始まり、110日での累 積メタン発生量は $18.4 \mathrm{~mol} / \mathrm{kg}-\mathrm{VS}$ となった。 $150^{\circ} \mathrm{C} の$ 熱処理条件の場合、未処理条件より遅れて 25 日目で ガス発生が始まったが、93 日目の累積メタン発生量 は 20.4mol $/ \mathrm{kg}$-VS であり、未処理の場合よりも $11 \%$ 増 加した。未処理と $150^{\circ} \mathrm{C}$ の熱水処理条件の実験終了時 点での累積メタン発生量の有意差検定を行ったとこ ろ有意水準 0.05 で有意差が認められた。Carrére ら 14) は、豚ふん尿を用いたバッチメタン発酵で COD 当 たりのメタン発生量が未処理より $150^{\circ} \mathrm{C}$ 熱処理液 の方が 45\%増加したと報告している。これは、d)で示 したように、Carrére ら ${ }^{14)}$ の場合、熱処理により酢酸 濃度が未処理の 4 倍になっているため、本研究の結 果よりも熱処理の効果が高くなったと考えられた。

表-3 バッチ実験で用いた熱水処理液および植種液 の性状

\begin{tabular}{|l|r|r|r|r|}
\hline $\begin{array}{l}\text { 熱水処理温度 } \\
\left({ }^{\circ} \mathrm{C}\right)\end{array}$ & 150 & 200 & 250 & 植種液 \\
\hline $\mathrm{pH}$ & 42,100 & 41,400 & 27,800 & 16,300 \\
\hline $\mathrm{TS}(\mathrm{mg} / \mathrm{L})$ & 30,800 & 30,400 & 19,000 & 10,900 \\
\hline $\mathrm{VS}(\mathrm{mg} / \mathrm{L})$ & 29,300 & 21,100 & 15,400 & 13,800 \\
\hline $\mathrm{SS}(\mathrm{mg} / \mathrm{L})$ & 13,600 & 11,100 & 6,970 & 8,490 \\
\hline $\mathrm{VSS}(\mathrm{mg} / \mathrm{L})$ & 9,630 & 10,570 & 9,790 & 1,085 \\
\hline TC (mg/L) & 9,630 & 10,570 & 9,790 & 890 \\
\hline $\mathrm{D}-\mathrm{TOC}(\mathrm{mg} / \mathrm{L})$ & 3,110 & 3,750 & 3,720 & 3,380 \\
\hline $\mathrm{T}-\mathrm{N}(\mathrm{mg} / \mathrm{L})$ & 2,440 & 2,490 & 2,320 & 3,380 \\
\hline $\mathrm{NH} 4-\mathrm{N}(\mathrm{mg} / \mathrm{L})$ & 41 & 42 & 41 & 34 \\
\hline $\begin{array}{l}\text { 固形物中 } \\
\text { TC }(\%-S S)\end{array}$ & 0.0 & 0.0 & 0.4 & 0.0 \\
\hline $\begin{array}{l}\text { 固形物中 IC } \\
(\%-S S)\end{array}$ & 2.5 & 1.7 & 2.0 & 5.4 \\
\hline $\begin{array}{l}\text { 固形物中 TN } \\
(\%-S S)\end{array}$ & & & \\
\hline
\end{tabular}

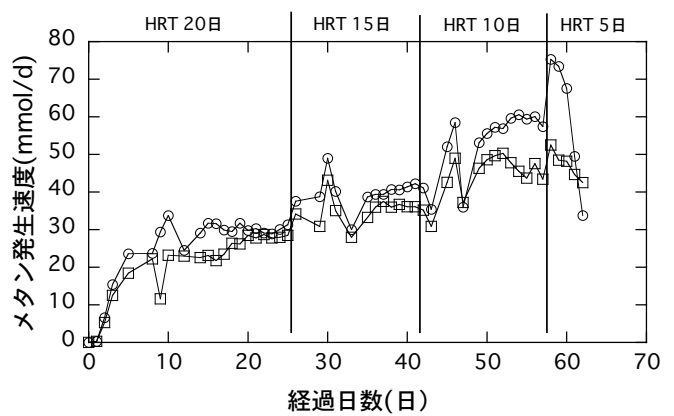

a) メタン発生速度 $200^{\circ} \mathrm{C}$ で処理した場合は 40 日目でメタン発生が始ま り、 $150^{\circ} \mathrm{C}$ の場合よりも長い馴致期間が必要であった。 また、実験開始後 110 日目でもメタンガス発生が認 められ、 $250^{\circ} \mathrm{C}$ の場合は、未処理や $150^{\circ} \mathrm{C}$ の場合より もメタン発生速度が遅いことが分かった。 $250^{\circ} \mathrm{C} て ゙$ 処 理した場合は実験開始後 110 日目でもメタンの発生 は見られなかった。

熱処理温度が高くなるとメイラード反応により、阻 害物質であるメノライジンが生成すると言われてい る ${ }^{12)}$ 。 $200^{\circ} \mathrm{C} は 250^{\circ} \mathrm{C} よ り も$ 低温なため、生成した阻 害物質の量が少ないため、微生物の馴致が可能で、 ガス発生時期が遅れたが、ある程度のガス発生が可 能であったと考えられる。

以上より、連続培養実験には $150^{\circ} \mathrm{C}$ で処理した物を 用いることとする。

表-4 連続発酵に用いた基質の性状

\begin{tabular}{|l|r|r|}
\hline & 熱処理液 $\left(150^{\circ} \mathrm{C}\right)$ & 植種液 \\
\hline $\mathrm{pH}$ & 6.43 & 7.71 \\
\hline $\mathrm{TS}(\mathrm{mg} / \mathrm{L})$ & 69,300 & 21,400 \\
\hline $\mathrm{VS}(\mathrm{mg} / \mathrm{L})$ & 53,100 & 11,600 \\
\hline $\mathrm{SS}(\mathrm{mg} / \mathrm{L})$ & 42,000 & 16,800 \\
\hline $\mathrm{VSS}(\mathrm{mg} / \mathrm{L})$ & 30,600 & 9,180 \\
\hline $\mathrm{NH}_{4}-\mathrm{N}(\mathrm{mg} / \mathrm{L})$ & 1,330 & 1,220 \\
\hline $\mathrm{D}-\mathrm{TOC}(\mathrm{mg} / \mathrm{L})$ & 12,300 & 1,100 \\
\hline
\end{tabular}

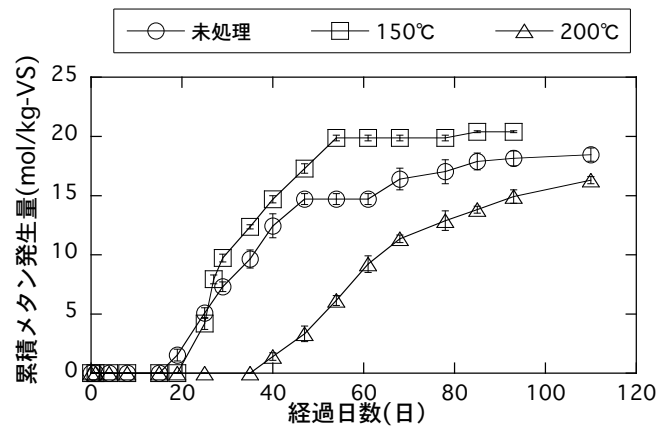

図-7 バッチ実験結果

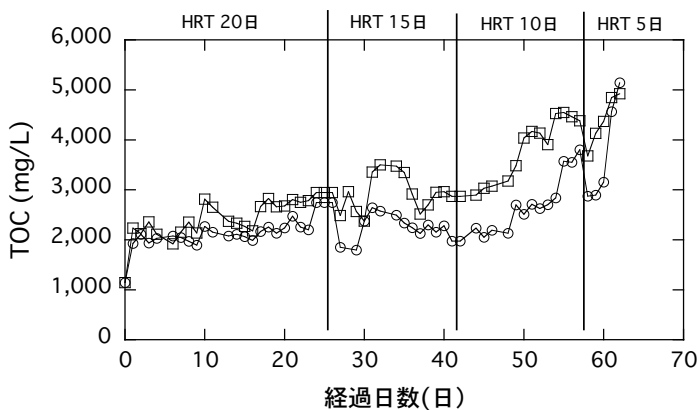

b ）発酵液中の D-TOC 濃度

図-8 連続メタン発酵実験結果 $(\bigcirc$ : 熱処理、 $\square$ : 未処理 $)$ 


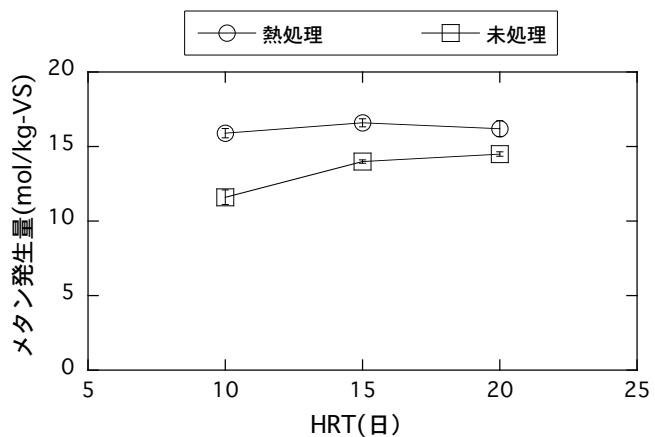

図-9 定常状態でのメタン発生量

\section{（3）連続メタン発酵実験}

表- 4 に連続メタン発酵に用いた熱水処理液と植種 液の性状を示す。図-8にメタンガス発生速度の経時 変化を示す。熱水処理の有無にかかわらず、メタン 発生速度はいずれも HRT10 日までは安定していたが、 HRT を 5 日に変更すると、メタン発生速度は急激に減 少した。実験開始後 63 日目でガス発生が止まったの で、実験を終了した。

図-9 に定常状態での投入VS あたりのメタン発生量 （HRT を変更する直前の 3 日間の平均値）を示す。VS あたりのメタン発生量は、熱処理を行った方が未処 理の場合よりも多くなり、熱処理によるメタン発酵 の向上が認められた。HRT15-20では熱処理した場合 の発生量は平均 $16.4 \mathrm{~mol} / \mathrm{kg}-\mathrm{VS}$ であり、未処理の HRT15-20 の值の 1.2 倍であった。これは、牛ふん尿 を $150-170^{\circ} \mathrm{C}$ で熱処理した連続メタン発酵の報告 $\left(1.3\right.$ 倍 ${ }^{13)}$ とほぼ等程度であった。

また、熱処理の場合 HRT10-20 の間でメタン発生量 はほぼ一定であるが、未処理の場合、メタン発生量 はHRT の短縮と共に減少した。このことから、熱処 理した方が滞留時間を短く寸ることができることが 分かった。

\section{（4）エネルギー収支の検討}

\section{a) エネルギー収支を検討する際の仮定}

上記より熱処理によりVS あたりのメタン発生量が 向上することが分かった。ここでは、熱処理により 正味の回収エネルギーが向上するかどうかを処理規 模 $\mathrm{Q}=1\left(\mathrm{~m}^{3} / \mathrm{d}\right)$ で検討した。検討するに当たって以下の 仮定を置いた。

未処理系の場合は、必要なエネルギーはメタン発酵 槽の加熱用のみとした。発生したメタンの持つエネ ルギーを回収エネルギーとした。熱処理系の場合は 必要なエネルギーは熱処理用のみとした。熱処理液 は熱回収し、熱回収後の熱処理液の持つエネルギー でメタン発酵槽を加熱することとした。回収エネル ギーはメタンの持つエネルギー及び熱処理液から回 収した熱とした。

未処理及び熱処理液について、密度 $\rho=1\left(\operatorname{ton} / \mathrm{m}^{3}\right)$ 、 比熱 $\mathrm{C}=4.2\left(\mathrm{MJ} /\left(\mathrm{ton} \cdot{ }^{\circ} \mathrm{C}\right)\right.$ とした。メタンの持つエ

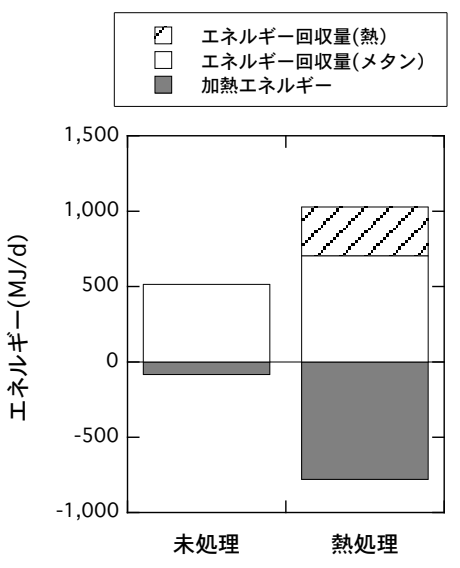

図-10 熱収支の比較

ネルギーの低位熱発熱量（M）は $0.082(\mathrm{MJ} / \mathrm{mol})^{13)}$ とした。豚ふん尿の温度 $t_{0}$ を $20^{\circ} \mathrm{C}$ 、メタン発酵槽の 温度 $\mathrm{t}_{\mathrm{F}}$ を $36^{\circ} \mathrm{C}$ 、熱処理温度 $\mathrm{t}_{\mathrm{T}}$ を $150^{\circ} \mathrm{C}$ とした。

メタン発酵槽の放熱によるロス $\mathrm{L}_{\mathrm{F}}$ は加熱量の $20 \%{ }^{13)}$ 熱処理槽での放熱による $\mathrm{L}_{\mathrm{T}}$ は $30 \%$ 、熱処理液からの 熱回収率 Rを 70\%とした。

熱処理によるVS の減少はないとして、熱処理液中 のVS 濃度は未処理液中の VS 濃度と同じであるとし た。VS あたりメタン発生量は実験で求めた HRT10 日 の結果を用いた。原料 VS 濃度は熱処理 D で用いた豚 ふ九尿の值を用いた。

\section{b) 計算方法}

\section{(1)未処理系の場合}

メタン発酵槽の加熱に必要なエネルギー量 (放熱に よるロス分を含んでいる） $\mathrm{H}_{\mathrm{F}}(\mathrm{MJ} / \mathrm{d})$ を次式で計算し た。

$$
\mathrm{H}_{\mathrm{F}}=\mathrm{Q} * \rho * C *\left(\mathrm{t}_{\mathrm{F}}-\mathrm{t}_{0}\right) /\left(1-\mathrm{L}_{\mathrm{F}}\right)
$$

メタンのエネルギー量 $\mathrm{H}_{\mathrm{M} O}(\mathrm{MJ} / \mathrm{d})$ を次式で計算し た。

$$
\mathrm{H}_{\mathrm{M} 0}=\mathrm{Q} * \mathrm{M} * \mathrm{G}_{0} * \mathrm{C}_{\mathrm{VS}}
$$

ただし、 $G_{0}$ は未処理液の VS あたりのメタン発生量 $(\mathrm{mol} / \mathrm{kg}-\mathrm{VS}) 、 \mathrm{C}_{\mathrm{VS}}$ は豚ふん尿中の VS 濃度 $\left(\mathrm{kg} / \mathrm{m}^{3}\right)$ である。正味の回収エネルギー量 $\mathrm{H}_{\mathrm{R}} \mathrm{O}(\mathrm{MJ} / \mathrm{d})$ を次式 で計算した。

(2)熱処理系の場合

$$
\mathrm{H}_{\mathrm{R} 0}=\mathrm{H}_{\mathrm{M} 0}-\mathrm{H}_{\mathrm{F}}
$$

熱処理槽の加熱に必要なエネルギー量（放熱による ロス分を含んでいる） $\mathrm{H}_{\mathrm{T}}(\mathrm{MJ} / \mathrm{d})$ を次式で計算した。

$$
\mathrm{H}_{\mathrm{T}}=\mathrm{Q} * \rho * C *\left(\mathrm{t}_{\mathrm{T}}-\mathrm{t}_{0}\right) /\left(1-\mathrm{L}_{\mathrm{T}}\right)
$$

回収される熱エネルギー量 $\mathrm{H}_{\mathrm{HT}}(\mathrm{MJ} / \mathrm{d})$ を次式で計 算した。

$$
\mathrm{H}_{\mathrm{HT}}=\mathrm{Q} * \rho * C *\left(\mathrm{t}_{\mathrm{T}}-\mathrm{t}_{\mathrm{R}}\right) * \mathrm{R}
$$

ただし、 $t_{R}\left({ }^{\circ} \mathrm{C}\right)$ は熱回収後の処理液温度である。 メタン発酵槽の保温に必用な熱量は熱回収後の処理 液の持っている熱量と考え、メタン発酵槽での放熱 によるロスを $20 \%$ 、外気温を $20^{\circ} \mathrm{C}$ とすると、以下の 式が成り立つ。

$\mathrm{Q} * \rho * \mathrm{C} *\left(\mathrm{t}_{\mathrm{R}}-\mathrm{t}_{\mathrm{F}}\right)=\mathrm{Q} * \rho * \mathrm{C} *\left(\mathrm{t}_{\mathrm{F}}-20\right) * 0.2$ 


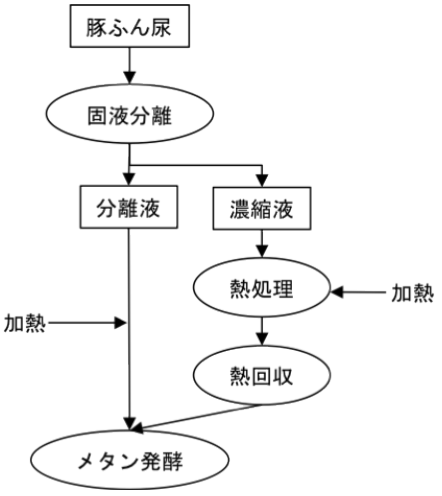

図-11 改善フロー

これより、 $\mathrm{t}_{\mathrm{R}}$ は $40^{\circ} \mathrm{C}$ となる。

メタンのエネルギー量 $\mathrm{H}_{\mathrm{MT}}(\mathrm{MJ} / \mathrm{d})$ を次式で計算し た。

$$
\mathrm{H}_{\mathrm{MT}}=\mathrm{Q} * \mathrm{M} * \mathrm{G}_{\mathrm{T}} * \mathrm{C}_{\mathrm{VS}}
$$

ただし、 $\mathrm{G}_{\mathrm{T}}$ は熱処理液のVS 当あたりのメタン発生量 (mol $/ \mathrm{kg}-\mathrm{VS})$ である。

正味の回収エネルギー量 $\mathrm{H}_{\mathrm{R} T}(\mathrm{MJ} / \mathrm{d})$ を次式で計算 した。

\section{c) 熱収支結果}

$$
\mathrm{H}_{\mathrm{RT}}=\mathrm{H}_{\mathrm{MT}}+\mathrm{H}_{\mathrm{HT}}-\mathrm{H}_{\mathrm{T}}
$$

図-10に未処理と熱処理の場合のエネルギー回収量 （メタン、熱）および加熱エネルギーの比較を示す。 未処理の場合、正味の回収エネルギーは $430(\mathrm{MJ} / \mathrm{d})$ であった。熱処理をした場合、メタン、熱を含めた 回収エネルギーは未処理の場合の 2 倍であったが、 加熱エネルギーは 9 倍となり、正味の回収エネルギ 一は 249 (MJ/d) で未処理の場合よりも低くなった。す なわち、熱処理は正味のエネルギー回収に関して不 利であることが分かった。

\section{d) 改良提案}

熱的に不利な理由は、熱処理の加熱エネルギーであ ることから、図-11 に示すように豚示ん尿の固液分離 を行い、固形物濃度が高い濃縮液のみを熱処理する ことで熱処理に必用なエネルギーを削減することを 検討した。固液分離のパラメータとして、SS 濃縮比 Con と SS 回収率 Re を以下のように定義して、正味の 回収エネルギーを計算した。

$$
\mathrm{Con}=\mathrm{C}_{\mathrm{SS}-\mathrm{H}} / \mathrm{C}_{\mathrm{SS}}, \mathrm{Re}=\mathrm{M}_{\mathrm{SS}-\mathrm{H}} / \mathrm{M}_{\mathrm{SS}}
$$

ただし、 $\mathrm{C}_{\mathrm{SS}-\mathrm{H}}$ は濃縮液中の SS 濃度、 $\mathrm{C}_{\mathrm{SS}}$ は豚ふん尿中 の SS 濃度、 $\mathrm{M}_{\mathrm{SS}-\mathrm{H}}$ は濃縮液中の SS 重量、 $\mathrm{M}_{\mathrm{SS}}$ は豚ふん 尿中の SS 重量である。

また、固液分離前の豚ふん尿の容積を $\mathrm{V} 、$ 濃縮液の 容積を $\mathrm{V}_{\mathrm{H}}$ 残りの液 (分離液) の体積を $\mathrm{V}_{\mathrm{L}}$ とすると、 以下の関係が成り立つ。

$$
\begin{gathered}
\mathrm{M}_{\mathrm{SS}}=\mathrm{C}_{\mathrm{SS}} * \mathrm{~V}, \quad \mathrm{M}_{\mathrm{SS}-\mathrm{H}}=\mathrm{C}_{\mathrm{SS}-\mathrm{H}} * \mathrm{~V}_{\mathrm{H}} \\
\mathrm{V}_{\mathrm{L}}=\mathrm{V}-\mathrm{V}_{\mathrm{t}}
\end{gathered}
$$

式(9)、（10）より、 $V_{\mathrm{H}}$ は次式で表現される。

$$
\mathrm{V}_{\mathrm{H}}=\mathrm{V} \times(\mathrm{Re} / \mathrm{Con})
$$

また、濃縮液の熱処理液および分離液のVS あたり メタン発生量は連続実験結果から得られた熱処理及

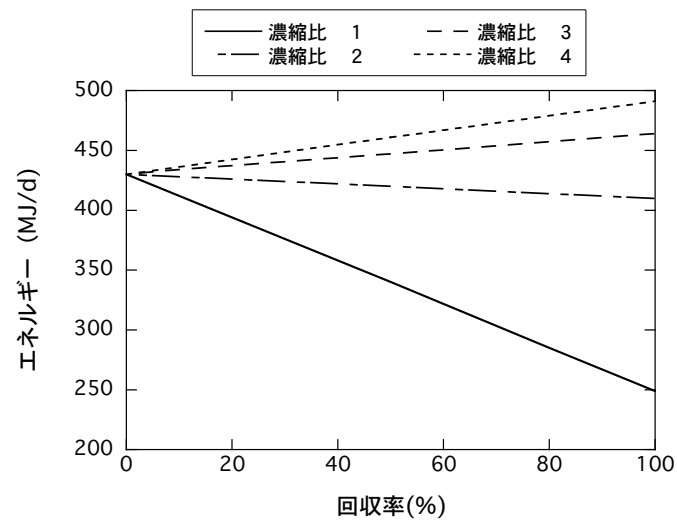

図-12 改善効果

び未処理の值を用いることができるとした。濃縮液 中のVS 濃度は熱処理によって変化しないとした。濃 縮液中のVS は揮発性固形物 (VSS) と揮発性溶存物質 (VDM)の合計量であり、その量はそれぞれ次式で表現 できる。

$$
\begin{gathered}
\mathrm{M}_{\mathrm{VSS}-\mathrm{H}}=\operatorname{Re} \times\left(\mathrm{C}_{\mathrm{SS}} \times \mathrm{V}\right) \times(\mathrm{VSS} / \mathrm{SS} \text { 比 }) \\
\mathrm{M}_{\mathrm{VDM}-\mathrm{H}}=\mathrm{C}_{\mathrm{VDM}} \times \mathrm{V}_{\mathrm{H}}
\end{gathered}
$$

ただし、 $\mathrm{C}_{\mathrm{VDM}}$ は豚ふん尿中の VDM 濃度である。また、 (VSS/SS 比) は原料豚ふん尿中の VSS と SS の比であり、 熱処理 Dの豚ふん尿の值を用いた。

分離液の VS は豚ふん尿中のVS から回収液中のVS を差し引いて求めた。

分離液のメタン発酵のための加熱エネルギー量 $\mathrm{H}$ F 、分離液から発生するメタンのエネルギー量 $\mathrm{H}_{\mathrm{M} 0}{ }^{\prime}$ 熱処理の加熱エネルギ一量 $\mathrm{H}_{\mathrm{T}}{ }^{\prime}$ 、熱処理液から回収さ れる熱エネルギー量 $\mathrm{H}_{\mathrm{H} T}$, 、熱処理液から発生するメ タンのエネルギー量 $\mathrm{H}_{\mathrm{MT}}$, 、正味の回収エネルギー量 $\mathrm{H}_{\mathrm{R} T}{ }^{\prime}$ は以下の式で計算される。

$$
\begin{aligned}
& \mathrm{H}_{\mathrm{F}}{ }^{\prime}=\left(\mathrm{V}_{\mathrm{L}} / \mathrm{V}\right) * \mathrm{H}_{\mathrm{F}} \\
& \mathrm{H}_{\mathrm{M} 0}{ }^{\prime}=\left(\mathrm{V}_{\mathrm{L}} / \mathrm{V}\right) * \mathrm{H}_{\mathrm{M} 0} \\
& \mathrm{H}_{\mathrm{T}}{ }^{\prime}=\left(\mathrm{V}_{\mathrm{H}} / \mathrm{V}\right) * \mathrm{H}_{\mathrm{T}} \\
& \mathrm{H}_{\mathrm{HT}}{ }^{\prime}=\left(\mathrm{V}_{\mathrm{H}} / \mathrm{V}\right) * \mathrm{H}_{\mathrm{HT}} \\
& \mathrm{H}_{\mathrm{MT}}{ }^{\prime}=\left(\mathrm{V}_{\mathrm{H}} / \mathrm{V}\right) * \mathrm{H}_{\mathrm{MT}} \\
& \mathrm{H}_{\mathrm{RT}}{ }^{\prime}=\mathrm{H}_{\mathrm{M} 0}{ }^{\prime}+\mathrm{H}_{\mathrm{MT}}{ }^{\prime}+\mathrm{H}_{\mathrm{HT}}{ }^{\prime}-\mathrm{H}_{\mathrm{F}}{ }^{\prime}-\mathrm{H}_{\mathrm{T}}
\end{aligned}
$$

SS 濃縮比と SS 回収率をパラメータとした正味の回 収エネルギーの計算結果を図-12 に示す。SS 濃縮比 1 とは固液分離を行わない条件に相当する。濃縮比 2.3 以上で熱処理した場合の正味の回収エネルギー は未処理の場合の正味の回収エネルギー (430MJ/kg) を上回ることができることが分かった。濃縮比 2.3 のときの回収液の SS 濃度は $122,000 \mathrm{mg} / \mathrm{L}$ であった。 豚ふん尿の機械的分離は設備費・運転費のコスト増 が予想されるが、豚舎でふん尿分離で排出されたふ ん（含水率 75\%、SS として 250,000mg/L） ${ }^{15)}$ を熱処理 してから尿と一緒にメタン発酵する方法も考えられ る。

\section{4. おわりに}

豚ふん尿のメタン発酵に対する豚ふん尿の熱処理 
効果を検討した結果、以下の知見が得られた。

(1) $200^{\circ} \mathrm{C}$ ま゙はVSS の可溶化が進むが、高分子の D-TOC 成分の VFA 化はあまり進まなかった。また、 $250^{\circ} \mathrm{C}$ ではさらにVSS の可溶化が進むと同時に、高分 子の D-TOC 成分の低分子化および若干のガスが進ん だ。

(2)熱処理温度が高くなるとメタン発酵開始時期お

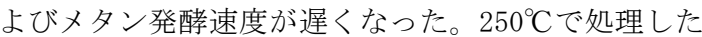
場合はメタン発酵しなかった。

(3) $150^{\circ} \mathrm{C}$ で熱処理した場合、熱処理なしの場合より も HRT を短くすることができた。また、熱処理によ り投入 VS あたりメタン発生量は 1.2 倍になり、熱処 理による効果が見られた。

(4)エネルギー回収の観点からは、熱処理を行う場合 は不利であり、SS 濃度を 2.3 倍以上に濃縮した液を 熱処理することで、熱処理なしに比べて正味のエネ ルギー回収が多くなると見積もられた。

【謝辞】本研究は、「文部科学省特別研究経費・連携 融合事業・農林畜産廃棄物利用による地域資源循環 システムの構築」による運営交付金によって行われ た。また、VFAの分析は宮崎大学工学部物質環境化学 科の横井春比彦教授の協力を得た。実験・分析は宮 崎大学工学部土木環境工学科学生 大坪潤司君の協 力を得た。ここに記して感謝いたします。

\section{【参考文献】}

1) http://www. maff. go. jp/j/chikusan/kankyo/tais aku/t_mondai/02_kanri/index. html 2012年3月31 日閲覧

2) http://www. maff. go. jp/j/press/2007/20070330p ress 6.htm1 2012年3月31日閲覧

3）宮西弘樹、木村彰宏、岩本雅志、石川宗孝、笠原 伸介、水熱反応処理の利用による厨芥を対象とし たメタン発酵の高効率化、廃棄物学会論文集、 Vol. 17, No. 1, pp. 23-30, 2006

4) R. W. Shaw, T. B. Brill, A. A. Clifford, C. A. Eckert, E. U1rich Franck, Supercritical water a medium for chemistry, Chemical and Engineering News, Vol.69, No.51, pp. 26-39, 1991
5) 向坊 隆、高温高圧水の化学-1-、電気化学および 工業物理化学、Vol. 32、No. 4、pp. 252-259、1964

6) 向坊 隆、高温高圧水の化学-2-、電気化学および 工業物理化学、Vol. 32、No. 5、pp. 336-341、1964

7）向坊 隆、高温高圧水の化学-3-、電気化学および 工業物理化学、Vol. 32、No. 6、pp. 416-423、1964

8）王偉、平岡正勝、武田信生、酒井伸一、後藤暢茂、 岡島重伸、嫌気性消化プロセスの前処理とする下 水污泥の熱処理に関する研究 一污泥固化物の可 溶化反応を中心として一、衛生工学論文集、Vol. 24, pp. 41-51, 1988

9) J. Pinnekamp, Effects of thermal pretreatment of sewage sludge on anaerobic digestion, Water Science and Technology, Vol.21, pp.97-108, 1989

10）今井剛、福田高史、村上定瞭、浮田正夫、関根 雅彦、樋口隆哉、亜臨界水を用いた下水污泥の資 源化に関する研究、環境工学研究論文集、Vol. 40, pp. 405-414, 2003

11) H. Yoshida, H. Tokumoto, K. Ishii, R. Ishii, Efficient, high-speed methane fermentation for sewage sludge using subcritical water hydrolysis as pretreatment, Bioresource Technology, Vol.100, No. 12, pp. 2933-2939, 2009

12) J.A. Müller, Prospects and problems of sludge pre-treatment processes, Water Science \& Technology, Vol.44, No. 10, pp. 121-128, 2001

13）米山豊、西井啓典、西本将明、山田紀夫、鈴木 隆幸、熱処理を組み込んだ牛糞尿の高効率メタン 発酵システム、廃棄物学会論文集、Vol. 17, No. 2, pp. 184-192, 2006

14) H. Carrére, B. Sialve, N. Bernet, Improving pig manure conversion into biogas by thermal and thermo-chemical pretreatments, Bioresource Technology, Vol. 100, No. 15, pp. 3690-3694， 2009

15）農文協、家畜環境対策大事典、農山漁村文化協 会、2000

(2012.5. 25 受付)

\title{
Effect of thermal treatment of pig manure on methane fermentation
}

\author{
Yutaka DOTE ${ }^{1}$, Tomoo SEKITO ${ }^{1}$, Yoshifumi GOTOH ${ }^{2}$, and Yoshihiro SUZUKI \\ ${ }^{1}$ Dept. of Civil and Environmental Engineering, University of Miyazaki \\ ${ }^{2}$ MIURA Co., Ltd
}

Thermal treatment of pig manure followed by batch and continuous methane fermentation was conducted in order to evaluate its effect on fermentation performance. Up to $200^{\circ} \mathrm{C}$ of thermal treatment, solubilization of VSS proceeded, but transformation of dissolved TOC with high molecule count into VFA was minimal. The high temperature led to retardation of initial gas generation and low gas generation rate. At $250^{\circ} \mathrm{C}$, no gas generation occurred. At $150^{\circ} \mathrm{C}$, methane generation per input VS with thermal treatment was 1.2 times greater than that without 
thermal treatment. The thermal treatment of standard pig manure was disadvantageous to net energy recovery. However, it was estimated that thermal treatment of manure with SS concentration of greater than 2.3 times the SS of standard manure increased net energy recovery over that without thermal treatment. 